\title{
LIMONADA À LA POE
}

António Corvo ${ }^{1}$

De um limoeiro um limão pergunta

A uma maçã, de madura, defunta

De que vale, ó dilema, esta vida, afinal

Se ele, que é azedo, e ela, que é doce,

Esta pra hoje, aquele, pr'um dia,

Todos os dois, numa queda invernal,

Terminarão, ele o crê, de forma tão precoce,

Seus dias de fruta em manhã fugidia?

Vacilante em seu caule, já sem equilíbrio,

Da macieira vizinha responde a maçã:

Vivi como pude e não me arrependo.

Não acho que haja na vida tal brio,

Achar um sentido em matéria tão vã.

Desde a semente é que se vai morrendo,

$\mathrm{E}$ isto é tudo a cumprir-se no mundo.

E nisso ficaram as frutas o resto do dia inteiro:

O limão e uma angústia azedinha, a maçã realista e descrente.

À noite vieram as estrelas, e com elas o bom fazendeiro,

Com cestas e uma foicinha, à cata, impiedosamente.

${ }^{1}$ Doutorando da Universidade Federal Fluminense. 
Em frente ao pé de limão, "tão bão" cheiro de limoeiro, Achou o limão saboroso, inchado de suco e cheiroso, Cortou-o do galho com gosto, partiu-o ali mesmo e chupou-o, Deixando do existencialista, só casca, bagaço e o cheiro.

Chegada a vez da maçã, brilhante 'causa do luar, Madura demais, moribunda, nem doce, nem outro manjar. A ela também veio a foice, salvou-lhe do chão o samburá, "Esta está boa pros porco, pra modi a lavagem engrossá".

Um corvo-preguiça que ali no pomar, Ouvira a conversa e a morte chegar, Profundo suspiro, longínquo, soltou, E meditabundo consigo falou:

Foi-se o limão em cruel limonada, Achou finalmente da vida o sentido.

E à velha maçã tão desesperançada, Coube ser alimento de porco nutrido.

E depois de irônica filosofia,

Disse ainda, o corvo, em tom de zombaria:

-É por isso que só como carne.

E ainda:

- Frutas, nunca mais. 